\title{
ON THE PRODUCTION OF MY FAIR LION AND HIS PRIDE: A REFLEXIVE EXERCISE IN ORAL HISTORY
}

\author{
Maarman Samuel Tshehla \\ University of South Africa \\ tshehms@unisa.ac.za
}

\section{ABSTRACT}

My fair lion and his pride is an autobiographical narrative of the life story of a respected and beloved, yet reserved and unlettered matriarch. The pleasure of capturing her recollections befell the present author. Consequently, the task of reflecting on the process that led to the production of My fair lion has also befallen him. In the present reflection, the author undertakes a retrospective journey guided by questions pertaining to oral history methodology. The dynamics of an individual remembering past events; the place of formal literacy in memory formation and retrieval; the role of the oral historian in oral history interviews and such other issues are indirectly explored below. In the end, it appears that while this author's preceding ignorance of oral history considerations may have disadvantaged the production of My fair lion, the latter retains and communicates sufficient qualities not of a grand narrative, but of a down-to-earth Christian mother, wife, and in-law.

Keywords : My fair lion; autobiographical narrative; reflections; oral history; remembering

\section{UNISA $\cong$}


While on research and development leave, the author spent about four months interacting with his octogenarian mother regarding both her life story and their family story. This communicative interaction took place intermittently between January and May 2015, alternately at the homes of the interviewee and the interviewer; both domiciles are situated within the Gauteng Province of South Africa. There was even a joint trip in March to the funeral of her older sister's son in Limpopo. The interviewer took advantage of the excursion to further clarify some geographical and other pertinent issues. It was a rare privilege to observe the interviewee as she physically and emotionally revisited the region of her childhood.

The interviewer was born and raised, like the majority of his siblings, in Boipatong at the southern base of the Transvaal. Unlike several of his siblings, he has never spent any sustained amount of time in Sekhukhuneland, from where his parents derive. Occasions such as weddings and funerals are just about the only times he has visited with his north-eastern relatives. Being the eighth of the interviewee's 10 surviving children and having such scant exposure to the north-eastern Transvaal, rendered him somewhat of an outsider vis-à-vis much of the family history. However, unlike a total stranger, he grew up exposed to anecdotes about certain key incidents and stories relating to some of the relatives. Moreover, rapport was established between him and the interviewee over the more than four decades of their motherson relationship.

On the one hand, this limited familiarity with the family story would allow him to interrogate things he had heard, but about which he lacked clarity. On the other hand, it would sufficiently assure the interviewee that her divulgences were being entrusted to someone who is heavily invested in the family's survival. In other words, the journey of producing My fair lion (Tshehla 2015) entailed as much the education of this author as it involved preserving the ruminations of a proud family's matriarch.

Thanks to the prompting of an esteemed senior colleague, the author has subsequently developed an interest in oral history methodology. In what follows, he reflects on the oral historical implications of the experience out of which the autobiographical narration of My fair lion emerged. This critical reflection lays bare several themes and questions, to which we now turn.

\section{PRELIMINARY DISCLOSURES}

The story matters to this author because it concerns his own heritage. Given the advanced age and increasing physical fragility of the family matriarch, it seemed vital and urgent that her memory should be explored and the family history be recorded for the benefit of the clan's younger members. The exercise was not entirely altruistic, even though she heartily welcomed the crystallisation of her recollections into a book. It is difficult to fully recount the emotional thrill that talking about the 
past appeared to elicit in her. She seemed to grasp that her life story will certainly have a positive influence on many others, and so she determined to tell it with that goal in mind. While a most excellent stance, this also meant that details deemed non-pedagogical would be left out or rationalised in ways that should minimise their unpalatable effect.

Regardless of how earnest she was towards the project, reality is that the author too had developed many questions over the years about the family story. Questions kept arising from things heard in passing and in various extended family contexts about which very little else had been said previously. The biggest impetus came from a birth certificate of a brother, only a year younger than the author, which had never been talked about before or since that day. Earlier attempts to find out more about him had been dismissed on grounds of the author being too young to deserve knowing. Thankfully, that is now no longer the case.

So, there is a family matriarch who wishes to have her life story preserved for posterity, largely because she sees it as a testimony of God's goodness towards both her and her labour of love. Then there is a son who seeks to improve his own knowledge and understanding of the family narrative, as well as to see a physical monument bearing his name, resulting from this process. But the author has siblings, some of whom tower rather mightily over him. Many among his older siblings have already accomplished much in life. How would the contents of this exposé impact their lives? Moreover, the extended family and other persons, whose names get mentioned in the story, also deserve sensitive consideration of one form or another. Other entities, such as the places and institutions mentioned, also have a less direct but no less real interest in the story.

Yet the story needs to be authentic, otherwise it is not worth telling. It has to be such that any interested party can follow up and independently verify its claims. Its incompleteness goes without saying, seeing inter alia that it is no more than the recollections of an octogenarian. Its significance, however, should grow as it gets employed in future 'intergenerational remembering and dialogue' projects, wherein 'members of different generations' participate in 'memory construction' for the sake of a fuller and more instructive family story. ${ }^{1}$ So while the author did consult other siblings for the verification of facts, he is painfully aware of the inescapable onedimensional character of My fair lion's reminiscences. But is this one-dimensional quality such a horrible thing? We argue in the next section that there are credible mitigating circumstances on the basis of which the recording of My fair lion deserves its place in the sun.

1 Alexander Freund, 'A Canadian family talks about Oma's life in Nazi Germany: Threegenerational interviews and communicative memory,' in The Canadian oral history reader, ed. Kristina R. Llewellyn, Alexander Freund and Nolan Reilly (Montreal \& Kingston: McGillQueen's University Press, 2015), 161. 


\section{CELEBRATING A MATRIARCH}

The oral history paradigm may have moved "beyond the unidirectional "handing down" and "receiving" between the old and the young" because memories are neither fixed nor complete entities but involve ongoing negotiations. Yet the place for extensive life stories has not diminished. After all, the rationalisation of memories occurs in later generations in interaction with changed social circumstances. Such inevitable rationalisation renders quite urgent the careful apprehension of eyewitness accounts which later appropriations can responsibly engage. This is quite significant in semi- or non-literate cultures where researchers barely have written accounts produced by 'the people' with which to work. ${ }^{3}$ As African wisdom would have it, the death of an elder is tantamount to the burning of a library, ${ }^{4}$ unless of course the elder's knowledge and wisdom have been captured in some enduring form (e.g. by griots or in book format). My fair lion is best seen, then, as a mother-grandmother's participation in cross-generational negotiations and interpretations of a growing family story.

My fair lion certainly was not intended to chronicle every single significant development relating to the family story, or even to each of its members. On the contrary, it was always explicitly intended as the family matriarch's own memoir. Making the story public should never be permitted to detract from its very personal agenda. The goal which excited the story's chief narrator was the possibility of leaving behind for posterity's benefit her own take on how far the family has come. Seen this way, variant interpretations of the events related in the book are anticipatable and, frankly, quite welcome.

While the memory of an 82-year old need not be acutely sharp, it is quite reasonable to expect some repression, some loss of detail, some conflations, some transpositions, some harmonising, some selectivity, some myth-making, and so forth. But these 'distortions' are not simply a function of age, neither are they restricted to the discipline of oral history as such. In oral history, as in other forms of interrogation, the onus to sift and separate fact from fiction remains squarely on the shoulders of those who consider themselves informed. The author was not able at the

2 Freund, 'A Canadian family,' 161.

3 Given the 'dearth of documents written by ordinary people' (Philippe Denis, 'Introduction' in Orality, memory and the past: Listening to the voices of black clergy under colonialism and apartheid, ed. Phillipe Denis [Pietermaritzburg: Cluster, 2000], 1, citing Luli Callinicos's), Denis explains how 'Oral history' emerged in 1980s South Africa with the express aim 'to improve the knowledge of the past by documenting the destinies of otherwise ignored people' (Denis, 'Introduction', 2).

4 The idea gets expressed in various guises and tongues, but the core and basic message is this: 'Whenever an elder dies, a library is burned to the ground' (Mirium Byekwaso and Gemma Burford, 'Mobilising young people in the documentation and conservation of oral heritage: A case study from Tanzania,' in The power of oral history: Memory, healing and development, eds. Phillipe Denis and James Worthington [Pietermaritzburg: Sinomlando Project, 2002] 1). 
time of the interviews to go as far as one trained in oral history methodology might have gone. Furthermore, as a much junior son, the author was not, from a cultural sensitivity ${ }^{5}$ point of view, permitted to challenge beyond certain boundaries.

The author's siblings shared his conviction that the project's 'greatest value' had to do with deepening understanding of their family history which in turn should 'enhance [their] own sense of identity'. ${ }^{6}$ They all welcomed the project and keenly went through the eventual manuscript to check for factual errors. Beyond the green light, they also supplied the scant photographs from the 1970s and 1980s, many of which made it into the book; poverty precluded photographs from before the late 1970s. Having so many older siblings, the author could do with all the help he could get from those who had witnessed first-hand some of the events under review within the pages of My fair lion. Their corroborative and corrective inputs were given and received with the understanding that the story is that of their mother, and thus her perspective as narrator remained paramount.

It can safely be argued that the greatest beneficiary of My fair lion is the project's primary source, the matriarch. 'For people who are interviewed, particularly older people, reviewing their life experiences and trying to order them and articulate their significance can be a rewarding experience. ${ }^{7}$ As an 82-year old, barely able to read and write her mother tongue, having had only two years of formal schooling, she reads her Sepedi Bible practically every day, and that is about all she can read with confidence because, even in this regard, her aural memory functions to the same if not higher extent than her ability to decode groups of letters on a page. She takes great pride in having My fair lion interpreted for her (the book is written largely in English), especially those parts where she pays homage to her late husband. One cannot miss her beaming satisfaction at the reality signified by the book to the effect that their life as a couple was not in vain.

\section{A REMARKABLE MEMORY}

What a remarkable capacity to recall. Many days the author sat there in awe of her ability to go back in time and link 'specific historical moments' to her own 'life

5 Landman, who works mostly with wounded and vulnerable persons, urges awareness of the need for 'sensitivity towards the culture(s) of the interviewee while simultaneously inviting the interviewee to move towards a contra-culture, an alternative story of hope, a story of resistance against oppression and exploitation' (Christina Landman, 'Teaching oral history,' in Oral history: Representing the hidden, the untold and the veiled, ed. Christina Landman, [Pretoria: RITR, 2013a], 185-6).

6 Linda Shopes, 'Using oral history for a family history project,' in Oral history: An interdisciplinary anthology, ed. David K Dunaway and Willa K Baum, 2nd edition.(Walnut Creek: AltaMira Press, 1996), 232.

7 Shopes, 'Using oral history,' 232. 
history and family history. ${ }^{8}$ The author's experience as well as his admiration of her memory, which obviously began long before he had formally decided to record her life story, affirmed in every way the truism that: 'Oral history is an expression of the personality of the interviewees, of their cultural values, and of the particular historical circumstances which shaped their point of view. ${ }^{9}$ Over many retellings in different contexts, the consistency of her story persisted, thereby confirming the view that her interpretations and association of her life story with various key external moments had sufficiently crystallised. She may get the exact year wrong, but the actual events as well as how they impacted on her life, she will not get mixed up.

Not only had her life story emerged over time, she had also mastered the 'many related and unrelated events and perceptions ${ }^{10}$ which when taken together, come to constitute this remarkable life. She could jump from one topic to another without feeling interrupted, and she did not contradict herself in matters of how some event influenced or was influenced by others. One needed to be both skilful and patient, since the Tshehla matriarch does not prefer to have the spotlight focused on her. She is happier when she is relating the selfless exploits of others around her over the years, and the depth of detail with which she sings others' praises, is equally astounding.

For the author, comparing such ability for recall to his own ability was inevitable and fairly traumatic. The author could not help feeling that sustained exposure to literacy over many years had robbed him of some potentially innate capacity to retain experiences encountered and observations made throughout one's life. Learning that the problem was fairly widespread helped somewhat. It is astounding that nonliterate or semi-literate persons should have such highly developed capacities of recall while those of us who work daily with letters will barely survive without pen and pad, not forgetting the smartphone. 'The reason it astounds us is because in our culture we have become so conditioned to the crush of print that most people in our culture have almost forgotten what the human memory is capable of if it is trained to keep things in it. ${ }^{11} \mathrm{O}$ the bliss of being able to link fairly directly and vividly one's own personality, one's cultural values, and the specific historical circumstances encountered in life, along with one's interpretations thereof.

While her perspective dictated the story's direction, the author's role was mainly to challenge, within acceptable cultural limits, what he deemed to be simplistic associations or unwarranted deductions and so forth. The extent of success in this

8 Tamara Hareven, 'The search for generational memory,' in Oral history: An interdisciplinary anthology, ed. David K Dunaway and Willa K Baum, 2nd edition (Walnut Creek: AltaMira Press, 1996), 242.

9 Hareven, 'The search for generational memory,' 247.

10 Landman, 'Teaching oral history,' (2013a) 185.

11 Alex Haley, 'Black history, oral history, and genealogy,' in Oral history: An interdisciplinary anthology, ed. David K Dunaway and Willa K Baum, 2nd edition (Walnut Creek: AltaMira Press, 1996), 268. 
regard falls beyond the author's ability to assess. It is for readers of the book to determine whether or not 'the information gathered' and presented in My fair lion amounts to anything more than 'a random collection of unrelated facts, anecdotes, and insights. ${ }^{12}$ The author did not beforehand impose a theme around which to shape the narrative. In this way, re-traumatisation was avoided as she voluntarily brought up those aspects of her life that she was comfortable to go into, and all the author did - now that he was old enough to be trusted with these family gems - was to strive to interrogate them for coherence and historical reliability. But what else might he have missed on account of being untrained in oral history at the time of writing? How might the presentation of the Tshehla matriarch's life story have been affected if he had undergone oral history training prior to writing the book?

\section{ORAL HISTORY QUESTIONS}

First of all, the author would most likely have made more use of a voice recorder than was actually the case. The only time he recorded his primary source's voice was in relation to the clan's praise poetry. Since he was already fairly familiar with the chief landmarks of the story, shorthand note-taking seemed sufficient. He remains confident that he has faithfully represented the narrative as entrusted to him, and he duly followed up points in later discussions where his notes presented lacunae. Nonetheless, he readily concedes that the vocally recorded portion of the interactions has become more precious to him as the family historian than even the printed book itself. No matter how skilfully put together, ink on paper can never outshine the tones and emotions carried by a living voice in its mother tongue natural habitat. So in retrospect, efforts to have the entire story preserved in the primary source's own voice might have been most rewarding. We cannot even have the published memoir read and recorded in her voice because of its general English medium with which she is not acquainted. Only the clan praises, two of her husband's favourite hymns, and a few other terse maxims are preserved in the text via her mother tongue medium.

Secondly, the published story was repeated as told by the primary source. The author did not beforehand choose a singular theme around which to organise the narrative. 'In the autobiographical interview,' and My fair lion was conceived as the matriarch's self-told life story from beginning to end, 'the course of the individual interviewee's life is what determines both the form and content of the oral history. ${ }^{13}$ This allowed the source to retain the story as hers whilst the author could always follow up on unclear aspects or misapprehensions of earlier assertions. On the whole she obliged queries and as far as she was comfortable she clarified what to the author

12 Shopes, 'Using oral history,' 234.

13 Sherna Gluck, 'What's so special about women? Women's oral history,' in Oral history: An interdisciplinary anthology, ed. David K Dunaway and Willa K Baum, 2nd edition (Walnut Creek: AltaMira Press, 1996), 218. 
seemed jumbled. And, naturally, where her narrative presumed an audience familiar with some geography or familial connections, it then befell the author to tersely explicate such connections in the written account.

Thirdly, given the author's interest in the implications and meanings of things, a moment or two of 're-traumatisation" ${ }^{14}$ threatened to surface. These generally arose around the part of the story which concerns her earliest interactions with the author's father's family. It intrigued the author that such emotional breakdown did not threaten her recollections of life with his late dad. She blossomed when she spoke of how he came to know about her as well as about their later life together struggling to raise a family. Talking about her life as a wife seemed therapeutic for her, as opposed to talking about her life as a makoti (daughter/sister-in-law) which she is much happier to forget. ${ }^{15}$ And yet she still made a point to clarify that relations did improve between her and her in-laws thanks in no small part to her own determination to make things work. Given her enthusiastic approval of the project and even the talk she subsequently gave at a women's gala event held at a hotel on the banks of the Vaal River, the author is fairly confident that his 'forcing' her to relive in some detail those traumatic memories has evaded 'doing more harm than good. ${ }^{16}$ On the contrary, it seems to have energised her to confidently and more openly talk to younger women about the challenges and joys of married life, specifically the incomparable joys and challenges of being both a wife and a makoti.

Since the author harboured no interventionist goals, he leans towards the view that talking about the past, whether a traumatic or a pleasant past, is in itself quite rewarding and perhaps even therapeutic in its own right. ${ }^{17}$ There is barely a need for the oral historian to emerge the hero of another's story, who is thus rendered passive by interventionist ambition. If the story is received and framed in terms of the interviewee's grasp of the course of her own life, such affirmation of one as ordinary as the next person must surely go a long way towards liberating the interviewee, regardless of the interviewer and his or her lofty objectives. In the Tshehla mother's case, for instance, she sees taking her maiden air trip as part of her eightieth birthday celebrations as evidence of just how blessed she is. In other words, the author's intervention as interviewer was not required since in her own eyes her story has a happy ending, and she is ever at pains to ensure that her hearer understands this

14 Anna Bryson and Seán McConville, The Routledge guide to interviewing: Oral history, social enquiry and investigation (London: Routledge, 2014), 15.

15 'Interviewers should remember that the information they are requesting is often connected to intense feelings', therefore 'it is crucial to give interviewees the time to tell stories that are meaningful to them.' (Sean Field, 'Dialogues of trust: The value of oral history in developing people,' in The power of oral history: Memory, healing and development, eds. Phillipe Denis and James Worthington [Pietermaritzburg: Sinomlando Project, 2002] 27).

16 Bryson and McConville, Routledge, Guide to interviewing, 15.

17 See elucidation by Christina Landman, 'The (de)construction of religious identity in oral history research in South Africa,' SHE 39,1 (2013b): 247-8. 
reality. It is as though the painful and ugly experiences were meant precisely to ensure that the end is so glorious as to more than compensate for the earlier trauma. There is an undeniable appreciation of life which, clearly, is informed in significant extent by the losses and struggles suffered much earlier on.

It seems therefore that 'aftercare ${ }^{18}$ was unnecessary, despite the author being untrained in oral history methodology at the time of producing My fair lion. The author should take some credit for insisting on some possible connections between "events and perceptions' ${ }^{19}$ even though he left it to her to decide whether or not such were plausible and worth explicating. Being a close family member thus held some benefits for the myth-making, whilst it also meant that he could not be forceful on some issues owing to his awareness of pertinent cultural sensitivities. As one who relies more on written texts than on oral ones, the author is also much more confident about his grasp of the family story.

From a personal point of view, the author must ask: Have I done justice to the stories of those involved? Did my writing transcend the façade of a mere "collection of individual biographies' and achieve an understanding of 'these individual lives in relation to the social circumstances that affected them'? ?20 It is left to readers of My fair lion to judge whether 'the information gathered' and presented in the book is more than 'a random collection of unrelated facts, anecdotes, and insights. ${ }^{21}$ The author appreciates that his limitations have prevented him from getting past the surface. A more qualified person might have drawn so much more out of the Tshehla matriarch and thus preserved for future generations the story of a life that is at once both typical of many African mothers and quite remarkable in its own right.

In conclusion therefore, the readers of My fair lion are invited to assess whether the presentation of the Tshehla matriarch's story upholds such skills as are deemed basic to every oral history interaction, including empathetic listening, making the interviewee feel really listened to, and asking questions in simple, brief and sensitive questions. ${ }^{22}$ To encourage the reader to acquire a copy of the memoir, this presentation is concluded with a brief synopsis of its main character.

\section{SYNOPSIS AS CONCLUSION}

$K o k i$, as she is affectionately known, hails from Glen Cowie to the south of Jane Furse. She is the fourth of her bishop-father's seven daughters and eight children in all. From a very tender age, she has always seen her life in terms of Christian ministry, albeit not in the conspicuous sense of her father's role but more along the

18 Landman, 'Teaching oral history,' (2013a) 188.

19 Landman, 'Teaching oral history,' (2013a) 185.

20 Shopes, 'Using oral history,' 233.

21 Shopes, 'Using oral history,' 234.

22 Field, 'Dialogues of trust,' 26. 
lines of the equally significant, though behind-the-scenes, role that her mother used to play. Brought up in the days of arranged marriages, when girls had no right to choose but only to be chosen, she was chosen in her early twenties by a fairly mature evangelist who came from the other side of Jane Furse. Having charmed her father, $M$ (as he called himself during the latter days of his life on this earth) went on to win Koki's heart and make an honest woman out of her. The couple was subsequently blessed with eleven children, one of whom passed on during the height of the family's tribulations. Of the surviving ten, only three are not directly involved in pastoral ministry. Beyond her own children, Koki's nurturing of more than 26 pastors in and around the Vaal Triangle was celebrated in 2015 by the region's women's forum. She remains the most down to earth individual you will ever come across; happy to listen rather than to speak, happier to give than to receive, happiest when relating the excellence of her husband, her mom and dad, and other persons she regarded as role models over the years.

In retrospect, the author fears that as currently printed, the book does not begin to do this unassuming Christian character adequate justice. His wishful regret remains: 'If only I were more qualified and more eloquent and not so close to her...'

\section{REFERENCES}

Bryson, Anna and Seán McConville. The Routledge guide to interviewing: Oral history, social enquiry and investigation. London: Routledge, 2014.

Byekwaso, Mirium and Gemma Burford. 'Mobilising young people in the documentation and conservation of oral heritage: A case study from Tanzania.' In The power of oral history: memory, healing and development, edited by Phillipe Denis and James Worthington, 1-14. Pietermaritzburg: Sinomlando Project, 2002.

Denis, Phillipe. 'Introduction.' In Orality, memory and the past: Listening to the voices of black clergy under colonialism and apartheid, edited by Phillipe Denis, 1-8. Pietermaritzburg: Cluster, 2000.

Field, Sean. 'Dialogues of trust: The value of oral history in developing people.' In The power of oral history: Memory, healing and development, edited by Phillipe Denis and James Worthington, 15-29. Pietermaritzburg: Sinomlando Project, 2002.

Freund, Alexander. 'A Canadian family talks about Oma's life in Nazi Germany: Threegenerational interviews and communicative memory.' In The Canadian oral history reader, edited by Kristina R. Llewellyn, Alexander Freund, and Nolan Reilly, 159-178. Montreal \& Kingston: McGill-Queen's University Press, 2015.

Gluck, Sherna. 'What's so special about women? Women's oral history.' In Oral history: An interdisciplinary anthology, edited by David K Dunaway and Willa K Baum, $2^{\text {nd }}$ edition, 215-230. Walnut Creek: AltaMira Press, 1996.

Haley, Alex. 'Black history, oral history, and genealogy.' In Oral history: An interdisciplinary anthology, edited by David K Dunaway and Willa K Baum, $2^{\text {nd }}$ edition, 257-279. Walnut Creek: AltaMira Press, 1996. 
Hareven, Tamara. 'The search for generational memory.' In Oral history: An interdisciplinary anthology, edited by David K Dunaway and Willa K Baum, $2^{\text {nd }}$ edition, 241-256. Walnut Creek: AltaMira Press, 1996.

Landman, Christina. 2013a. 'Teaching oral history.' In Oral history: Representing the hidden, the untold and the veiled, edited by Christina Landman, 185-192. Pretoria: Unisa Press, 2013.

Landman, Christina. 2013b. 'The (de)construction of religious identity in oral history research in South Africa.' Studia Historiae Ecclesiasticae 39(1), 2013: 247-259.

Shopes, Linda. 'Using oral history for a family history project.' In Oral history: An interdisciplinary anthology, edited by David K Dunaway and Willa K Baum, $2^{\text {nd }}$ edition, 231-240. Walnut Creek: AltaMira Press, 1996.

Tshehla, M.S. My fair lion and his pride: The Tshehla matriarch relates her family's moving story. Johannesburg: Kalosong Publishers, 2015. 